\title{
The Relationship between Reputation and Behavior of Venture Capital Institutions under the Theory of Information Asymmetry
}

\author{
Qianwen Zhu \\ Department of Finance, College of Economics, Jinan University, Guangzhou, China \\ Email: 13760806829@163.com
}

How to cite this paper: Zhu, Q.W. (2019) The Relationship between Reputation and Behavior of Venture Capital Institutions under the Theory of Information Asymmetry. American Journal of Industrial and Business Management, 9, 315-324. https://doi.org/10.4236/ajibm.2019.92021

Received: January 7, 2019

Accepted: February 24, 2019

Published: February 27, 2019

Copyright () 2019 by author(s) and Scientific Research Publishing Inc. This work is licensed under the Creative Commons Attribution International License (CC BY 4.0).

http://creativecommons.org/licenses/by/4.0/

\begin{abstract}
With the rapid development of the mobile terminal, the investment around the mobile terminal has stimulated the investment of venture capital institutions to a large extent, and the research on venture capital has been increasing in recent years. Based on asymmetric information theory, to understand the behavior of venture capital from the perspective of reputation, game model, a venture capital and start-ups as well as numerous trade once earnings analysis, the venture capital firm focused on conditions for building a good reputation, and believed that the increase in the number of expected future transactions was an incentive for venture capital institutions to maintain a good reputation.
\end{abstract}

\section{Keywords}

Reputation of Venture Capital Institutions, Value-Added Services, Game Model

\section{Research Overview}

On September 19, 2013, Alibaba announced in the US market, Nasidake IPO market, that the IPO was priced at \$68; Alibaba's listing of the US stock market has become the largest IPO. The major shareholder holding Alibaba is not its founder Ma Yun, but the Softbank Group founded by Sun Zhengyi, a comprehensive investment company that invests more than 600 companies worldwide. The listing of Alibaba has undoubtedly increased the assets of Softbank, which has made Softbank create a "myth" of return on investment and set off a hot discussion on venture capital.

Ten years ago, China's e-commerce transaction volume was less than $1 \%$ of the global total. Now it accounts for more than $40 \%$ [1]. It is estimated to exceed 
the sum of the five countries of the United Kingdom, the United States, Japan, France and Germany. Mobile payment is available to Chinese Internet users. Population penetration is growing rapidly, up from 25 percent in 2013 to $68 \%$ in 2016, mobile payment transactions related to personal consumption and as much as $\$ 790$ billion, equivalent to 11 times the United States [1]. The rapid rise of the mobile side, the investment around the mobile side has greatly stimulated the investment of venture capital institutions. According to the "2011 China Enterprise Operators Growth and Development Special Investigation Report", information transmission computer services and software companies in 11 industries including agriculture, forestry, animal husbandry, fishery, mining and manufacturing have been implemented on the major financing methods that have been implemented in the past three years. The proportion of "introduction of private equity or venture capital" selected by the technology-based enterprises represented is the highest, reaching $27.5 \%$ [2]. In the major financing methods planned for the next three years, these technology-based enterprises choose "to introduce private equity or risk". The proportion of investment is $45.8 \%$ [2].

One-third of the world's 262 "unicorns" (private start-ups with a valuation of more than $\$ 1$ billion) are Chinese companies, accounting for $43 \%$ of the global unicorn company's total valuation; in the financial technology sector, globally 23 non-listed "unicorn" and there are nine Chinese companies, but also accounted for more than $70 \%$ of the total valuation of the global financial technology companies; Chinese venture capital industry from 2011-2013 years to $\$ 12$ billion (accounting for 6\% of the world) quickly rose 2014-2016 years of $\$ 77$ billion (accounting for $19 \%$ of the world) [1].

In addition to providing funds for enterprises, venture capital institutions also provide value-added services for their invested entrepreneurs, such as assisting enterprises in strategic planning, establishing a rational business model, improving management, and providing resources for enterprises. Why is there no Chinese venture capital institution to participate, why does Ma Yun seek to cooperate with foreign risk agencies? One of the reasons was that Sun Zheng's Softbank Group had a higher reputation and had a higher success rate for Alibaba's successful listing.

Venture companies with high reputation for venture capital support higher quality, and the company's accounting information quality is better, such investment is easier to succeed; in turn, the accumulation of successful investment experience will further enhance the reputation of venture capital institutions and enable venture capital institutions to raise more funds and find better investment targets more easily. Moreover, as an intangible asset, reputation is gradually accumulated in the long-term management process of the enterprise, representing the image and reputation of the company. An important feature of such assets is that they will be devastated once they are affected by negative information. High-reputation venture capital institutions are less likely to be prosecuted, and venture capital institutions that have been prosecuted can raise less funds in subsequent transactions, have fewer investment records, are less 
likely to succeed, and have fewer joint investments. Tian et al. (2016) studied the situation in which venture capital background companies were sued for accounting fraud after the IPO. It was found that after the company faced litigation, the behaviors of fundraising, investment, and exit of relevant venture capital institutions would be affected [3].

\section{Research Questions}

At present, the research on the reputation of venture capital is mainly to study its importance and research on the mechanism of action. Since the reputation of venture capital is so important, will all venture capital institutions choose to establish and operate a good reputation? How is the reputation of venture capital formed? What kind of considerations will venture capital institutions value and build reputation?

Based on the theory of information asymmetry, this paper establishes a game model, discusses the interaction between the reputation of venture capital institutions and their behaviors, and explains the impact of the reputation of venture capital institutions on the behavior of venture capital institutions and the incentives to encourage venture capital institutions to establish a good reputation. At the end of the article, I also considered the limitations of the model.

\section{Literature Review}

Gompers (1996) demonstrated the important role of venture capital reputation in the theoretical field for the first time, and proposed the theory of explaining the IPO discount of venture capital-"grand standing theory" [4]. He believes that young venture capital to build a reputation, in order to raise funds for the follow-up to the successful, will push its enterprises to invest in listed as soon as possible, and as a discount to IPO price. The underlying assumption is that the reputation of venture capital is formed by past good investment and exit records, and venture capital institutions can use IPOs to demonstrate their good reputation. This idea was endorsed by Hsu (2004). He believes that the reputation of venture capital institutions is formed in long-term market transactions and repeated games, and is an important mechanism to alleviate information asymmetry [5].

Venture capital research mainly involves three main entities: venture capitalists (including limited partners and general partners), venture capital institutions and start-ups. In actual operation, venture capital is invested in the form of venture capital funds, and the risk management institutions are the daily management and investment decisions of the fund.

The research on the reputation of venture capital mainly includes two aspects. First, the impact on the investment institution itself, the reputation of venture capital can bring benefits such as fundraising, relationship network, bargaining power and return on investment (Gompers, 1996; Hsu, 2004; Lee \& Wahal, 2004; Nahata, 2008; Ye Xiaojie and Shen Weitao, 2013) [4] [5] [6] [7] [8]. Second, the 
impact on entrepreneurial enterprises, the benefits of certification, value-added services and long-term performance for the entrepreneurs they invest in (Hsu, 2004; Gompers \& Xuan, 2009; Wu Chaopeng et al., 2012; Zhao Wei and Wen Jun, 2015) [5] [9] [10] [11]. The exchange of reputation information among various stakeholders, the formation of reputation information flow, reputation information system and reputation information network, becomes the information display mechanism, effectively limiting information distortion, increasing transaction transparency and reducing transaction costs.

There is no consistent conclusion on the research on the measurement of venture capital reputation. There are mainly the following methods: First, the IPO metrics supported by venture capital. Venture capital support over the number of IPO, venture capital support of IPO market capitalization (Krishnan et al., 2011) [12] and venture capital institutions to support the amount of IPO market share (Shu et al., 2011) [13]. Nahata (2008) proposed to measure the reputation of venture capital with the previous IPO market share of venture capital institutions, which directly promoted the development of measurement indicators [8]. Krishnan et al. (2011) borrowed and improved this metric to explore the relationship between venture capital reputation and long-term IPO corporate governance and corporate governance [12]. The second is the indicators of the venture capital institutions themselves. Total capital managed by venture capital institutions (Gompers \& Lerner, 1999a) [14], total investment by venture capital institutions, and age of venture capital institutions (Gompers, 1996; Hsu, 2004; Chen Gongmeng et al., 2011) [4] [5] [15]. The third is to build a reputation index. Petkova et al. (2014) [16] used the reputation index constructed by Lee et al. (2011) [17] to study the relationship between reputation and decision-making of venture capital institutions under fuzzy conditions.

As a special financial intermediary, venture capital institutions can not only provide capital support for enterprises, but also provide value-added services for enterprises. At the same time, they can play an authentication function between enterprises and external investors, and drive technological innovation and promote industrial transformation and upgrading. It plays an important role in the national economy, such as promoting economic development and increasing social employment. Many domestic and foreign scholars have done a lot of research on the reputation of venture capital institutions and the measurement of reputation. This paper mainly studies the establishment of a good reputation of venture capital institutions, and establishes a game model to study its incentive factors.

\section{Theoretical Analysis}

\subsection{The Determinant of the Reputation of Venture Capital}

According to the above literature analysis, the reputation of venture capital has a relatively large impact on the investment institution itself and on venture capital institutions. What needs to be understood before is the determinant of the repu- 
tation of venture capital, that is, how the reputation of venture capital institutions is formed, and its formation is closely related to investment performance, professional knowledge and capabilities, especially in the IPO market. The cost of being sued after a breach of contract can also have an impact.

The reason why venture capital institutions are closely related to reputation formation in the IPO market is: First, the IPO approach is considered one of the best ways for venture capital institutions to exit. There are three main modes for exiting venture capital institutions: IPO, equity transfer and liquidation. Equity transfer includes two modes of mergers and acquisitions and share repurchases. The exit of the venture capital institution is generally several times, dozens of times, or even hundreds of times of the initial investment. The profitability is far higher than exit through corporate mergers and acquisitions. Since bankruptcy liquidation is basically used when venture capital institutions are completely disappointed with investment projects or difficult to achieve the established capital appreciation, the investment performance of bankruptcy liquidation is very low, far lower than initial public offerings and mergers and acquisitions. From the perspective of the efforts of venture capital institutions, they are still mainly seeking to withdraw through the initial public offering. After all, profitability is still the most concerned by venture capital institutions. On the whole, the exit performance of the initial public offering is higher than that of corporate mergers and acquisitions, bankruptcy liquidation, and so on.

Secondly, the successful exit of the project with IPO will help to increase the attention and reputation of venture capital institutions. Megginson \& Kathleen (1991) [18] pointed out that Carlyle ( KPCB ) drove 10 companies to enter the securities market by IPO between 1983 and 1987, greatly increasing their exposure in the market.

In addition, the repeated successes in driving companies to IPOs will give venture capital institutions a greater chance of reaching potential investment opportunities in the future. Reputation and high-profile venture capital institutions are more attractive to entrepreneurs, and thus have the opportunity to invest in companies with growth potential, resulting in better performance and reputation.

\subsection{A Game Model to Discuss the Interaction between the Reputation of Venture Capital Institutions and Their Behaviors}

Based on the theory of information asymmetry, this paper establishes a game model, analyzes the impact of venture capital reputation and its behavior, and analyzes the incentive factors of risk investment institutions focusing on reputation.

The theory of information asymmetry means that if there is asymmetric information between the two parties, it is easy to generate adverse selection and moral hazard problems, and establishing incentive mechanism and signal transmission mechanism can reduce the problem of adverse selection and moral hazard. Reputation mechanism is an effective way to overcome the problem of 
information asymmetry between the two sides of the transaction, and the cyclical process of production, transmission, utilization, re-formation, re-transmission and reuse of reputation information. In this process, reputation information is constantly being updated. This article provides useful guidance for understanding the behavior of venture capital institutions from a reputation perspective.

In the analysis framework of Zheng Xiujie (2010) [19] and Zheng Xiutian (2015) [20], it is assumed that there is a venture capital institution in the venture capital market, which not only provides funds for enterprises, but more importantly, provides services for enterprises, especially Value depreciation service. The venture capital institution faces two choices in the provision of services. First, it provides quality services; second, it provides inferior services. The cost of providing quality services to venture capital institutions will be $C_{1}$ and the cost of providing inferior services will be $C_{2}$. If venture capital institutions want to provide quality services, they need to visit enterprises, communicate with entrepreneurs often, integrate resources for enterprises, and even participate in daily business management of enterprises, such as sending members to the board of directors, or sending members to become senior managers of enterprises. It will cost more than providing inferior services, so there is $C_{1}>C_{2}>0$; that is, the cost of providing quality services is higher than the cost of providing inferior services.

To simplify the analysis, assume that the customer's consumption of the venture capital institution's services is one unit. The non-monetary income obtained is $P$, and the non-monetary return is $Q$, which is reputation.

The income function of a venture capital institution is

$$
R=P+\lambda Q-C
$$

When venture capital institutions provide quality services,

$$
\lambda>0, R=P+Q_{1}-C_{1}
$$

When venture capital institutions provide inferior services,

$$
\lambda<0, \quad R=P-Q_{2}-C_{2}
$$

The above only considers the case of a venture capital institution trading once, considering its short-term gains. If it is assumed that the venture capital institution provides and sells quality services for the $t$ time, each transaction has a time interval, and the discount factor for each transaction period is $i$ (considering the time value of the funds, $i<0$ ).

Analyze the role mechanism of reputation in the long-term process. As reputation as an intangible asset, it is gradually accumulated in the long-term management process of the enterprise, representing the image and reputation of the company. An important feature of such assets is that they will be devastated once they are affected by negative information. The process of reputation mechanism is a cyclical process of production, transmission, utilization, re-formation, re-transmission and reuse of reputation information. In this process, reputation information is continuously updated, and reputable investment risk institutions 
can obtain more trading opportunities and more favorable transaction prices, thus accumulating reputation. However, the establishment and maintenance of reputation is a long process that requires long-term continuous efforts. Otherwise, once a derogatory act occurs, its reputation will be destroyed, and it will no longer be able to gain reputation and even be punished. Figure 1 shows the long-term process of simplifying the reputation of an investment institution.

Long-term effects of reputation, reflected in the non-monetary benefits $Q$, with $\varphi(Q)$ Said. The reputational return of venture capital that provides and sells quality services continuously is higher than that of venture capital institutions that provide inferior services, so $\varphi\left(Q_{1}\right)>\varphi\left(Q_{2}\right)$.

Then, after the transaction of providing and selling quality service $t$ times, the present value of the return of the venture capital institution is the sum of the present value of the income of each transaction.

$$
\begin{aligned}
& R_{1}=R_{11}+i R_{12}+i^{2} R_{13}+\cdots+i^{t-1} R_{1 t} \\
& R_{1}=\left(P+\varphi\left(Q_{11}\right)-C_{1}\right)+i\left(P+\varphi\left(Q_{12}\right)-C_{1}\right)+i^{2}\left(P+\varphi\left(Q_{13}\right)-C_{1}\right) \\
&+\cdots+i^{t-1}\left(P+\varphi\left(Q_{1 t}\right)-C_{1}\right) \\
&= \frac{1-i^{t}}{1-i}\left(P+\varphi\left(Q_{1}\right)-C_{1}\right)
\end{aligned}
$$

If a venture capital institution provides inferior services in the first phase, its utility in the current period is

$$
R_{2}=P+\varphi\left(Q_{2}\right)-C_{2}
$$

Therefore, in order for venture capital institutions to restrain opportunistic behavior, provide quality services to customers, and make reputational investments, the present value of providing quality services must be greater than the benefits of providing inferior services, that is, the following conditions must be met:

$$
\frac{1-i^{t}}{1-i}\left(P+\varphi\left(Q_{1}\right)-C_{1}\right)>p+\varphi\left(Q_{2}\right)-C_{2}
$$

When the value of $t$ and $i$ meet the above conditions, venture capital institutions will choose quality services and a good reputation will continue to accumulate. Since venture capital institutions may choose poor quality services to reduce costs, customers will no longer cooperate with them. This also verifies the

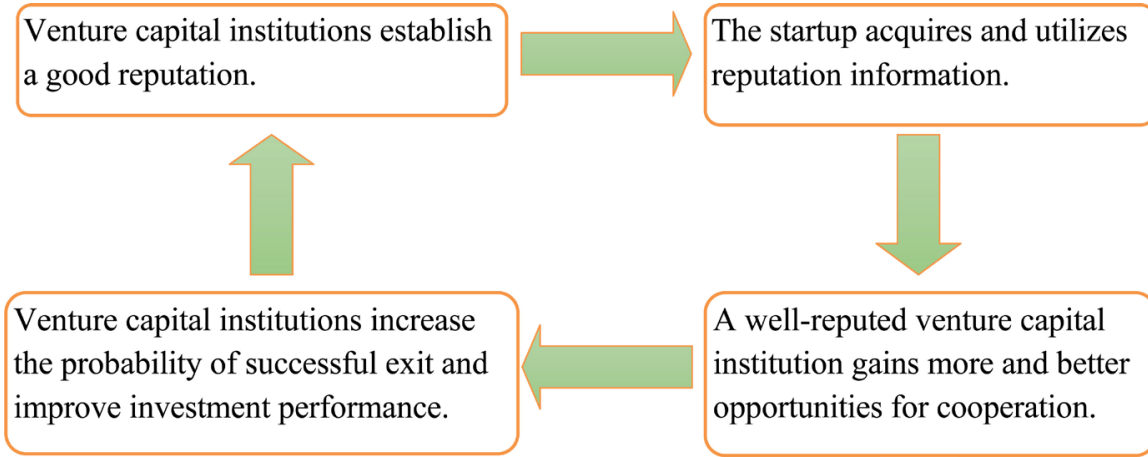

Figure 1. Simplified long-term process of investment institution reputation. 
views of Atanasov et al. (2011), Tian et al. (2016) that the reputation of venture capital institutions will be destroyed and the consequences will be significant.

How can we provide quality services to venture capital institutions and provide sufficient incentives for reputational investments? If the transaction is repeated indefinitely, Equation (4.1) becomes:

$$
R_{1}=\frac{1}{1-i}\left(P+\varphi\left(Q_{1}\right)-C_{1}\right)
$$

The total return of a venture capital institution that provides unlimited quality services minus the total benefit of providing inferior services is the difference in building reputation. Therefore, the conditions for venture capital institutions to meet their reputation investments are:

$$
\frac{1}{1-i}\left(P+\varphi\left(Q_{1}\right)-C_{1}\right)>P+\varphi\left(Q_{2}\right)-C_{2}
$$

Then,

$$
i>\frac{C_{1}-\varphi\left(Q_{1}\right)-C_{2}}{P+\varphi\left(Q_{2}\right)-C_{2}}
$$

due to $\varphi\left(Q_{1}\right)>\varphi\left(Q_{2}\right)$, so when $i$ does not change, $P$ continues to grow larger, and the rewards required for startups are greater. The smaller the cost, the smaller the cost of value-added services, and the more easily (4.5) is satisfied. In the long run, the impact of reputation is constantly accumulating, so the gap between $\varphi\left(Q_{1}\right)$ and $\varphi\left(Q_{2}\right)$ will be bigger and bigger. And because of the existence of learning effects, as the number of transactions increases, venture capital institutions will continue to accumulate experience and capabilities through each exploration and learning. As a result, the services provided by venture capital institutions will be more excellent, thus charging customers more. The premise of high prices, at the same time, with the number of transactions, the existence of learning effects also makes the cost of providing services to venture capital institutions will be lower and lower, therefore, as the number of transactions of venture capital institutions continues to increase, By providing better service behavior, venture capital institutions are increasingly motivated to build higher reputations.

The reputation of venture capital institutions is closely related to investment performance, professional knowledge and capabilities, especially in the IPO market. Based on asymmetric information theory to understand the behavior of venture capital from the perspective of reputation, game model, a venture capital and start-ups as well as numerous trade once earnings analysis, the venture capital firm focused on conditions for building a good reputation, And believe that the increase in the number of expected future transactions is an incentive for venture capital institutions to maintain a good reputation.

\section{Conclusion}

Based on the information asymmetry theory, this paper establishes the game 
model, conducts the risk investment institution and the startup enterprise transaction once and countless times of the income analysis, and concludes that the venture capital institution pays attention to the condition of reputation, and believes that the expected increase in the number of transactions in the future is an incentive for venture capital institutions to maintain a good reputation.

In connection with the actual situation, the analysis of the reputation model has its limitations. It only considers the choice behavior of both parties and does not consider the market environment factors. Since the transaction is conducted in the market, the reputation mechanism operates in the market, and the market environment is also an important factor influencing the behavioral choice of the two parties and the operational efficiency of the reputation mechanism. There are at least two prerequisites for the model to work: the effectiveness of the reputational penalty mechanism and the enthusiasm of the startup to use reputation information.

An effective reputation penalty mechanism can create a credible threat to the company, thereby inhibiting the opportunistic behavior of venture capital institutions, and making the company's commitment to venture capital institutions a credible commitment to increase the enthusiasm of using reputation information. China's law does not have enough constraints on the reputation of venture capital, coupled with relatively high litigation costs for startups, and the non-public opacity of information, which will affect the effectiveness of reputation punishment mechanisms and the enthusiasm of startups to use reputation information. In reality, the demand for venture capital institutions is in short supply. Large numbers of venture companies are less concerned with the reputation-restricting mechanism of venture capital institutions than a small number of venture capital institutions. This may also be the reason why most of the existing literature is about the reputation incentive mechanism, but lacks an in-depth discussion of the constraint mechanism.

\section{Conflicts of Interest}

The authors declare no conflicts of interest regarding the publication of this paper.

\section{References}

[1] McKinsey (2017) China in the Digital Age: Building a Globally Competitive New Economy. http://www.sohu.com/a/209620462_631360

[2] Chinese Entrepreneur Survey System (2011) Capital Market and Chinese Entrepreneur Growth: Current Situation and Future, Problems and Suggestions-2011 Special Report on Chinese Business Operator Growth and Development. Management World, 6, 76-90.

[3] Tian, X., Udell, G.F. and Yu, X. (2016) Disciplining Delegated Monitors: When Venture Capitalists Fail to Prevent Fraud by Their IPO Firms. Journal of Accounting and Economics, 61, 526-544. https://doi.org/10.1016/j.jacceco.2015.09.004

[4] Gompers PA. (1996) Grandstanding in the Venture Capital Industry. Journal of Financial Economics, 42, 133-156. https://doi.org/10.1016/0304-405X(96)00874-4 
[5] Hsu, D.H. (2004) What Do Entrepreneurs Pay for Venture Capital Affiliation? The Journal of Finance, 59, 1805-1844. https://doi.org/10.1111/j.1540-6261.2004.00680.x

[6] Lee, P.M. and Wahal, S. (2004) Grandstanding, Certification and the Underpricing of Venture Backed IPOs. Journal of Financial Economics, 73, 375-407. https://doi.org/10.1016/j.jfineco.2003.09.003

[7] Nahata, R. (2008) Venture Capital Reputation and Investment Performance. Journal of Financial Economics, 90, 127-151. https://doi.org/10.1016/j.jfineco.2007.11.008

[8] Ye, X.J. and Shen, W.T. (2013) Venture Capital Reputation, Joint Investment and Successful Exit. Journal of Shanxi University of Finance and Economics, 12, 46-55.

[9] Gompers, P.A. and Xuan, Y. (2009) Bridge Building in Venture Capital-Backed Acquisitions. Harvard Business School, Boston.

[10] Wu, C.P., Wu, S.N., Cheng, J.Y. and Wang, W. (2012) An Empirical Study on the Impact of Venture Capital on Investment and Financing Behavior of Listed Companies. Economic Research, 1, 105-119, 160.

[11] Zhao, W. and Wen, J. (2015) Can Venture Capital Interventions Improve the Performance of Strategic Emerging Industries? Industrial Economics Research, 3, 79-89.

[12] Krishnan, C.N.V., Ivanov, V.I., Masulis, R.W. and Singh, A.K. (2011) Venture Capital Reputation, Post-IPO Performance and Corporate Governance. Journal of Financial and Quantitative Analysis, 46, 1295-1333. https://doi.org/10.1017/S0022109011000251

[13] Shu, P.G., Yeh, Y.H., Chiu, S.B., et al. (2011) The Reputation Effect of Venture Capital. Review of Quantitative Finance and Accounting, 36, 533-554. https://doi.org/10.1007/s11156-010-0188-x

[14] Gompers, P.A. and Lerner, J. (1999) What Drives Venture Capital Fund Raising. Brookings Papers on Economic Activity: Microeconomics.

[15] Chen, G.M. and Yu, Y. (2011) Kou Xiang River Impact on Chinese Enterprises IPO Discount of Venture Capital Participation-To Compare the Stock Market. Economic Research, 5, 74-85.

[16] Petkova, A., Wadhwa, A., Yao, X. and Jain, S. (2014) Reputation and Decision Making Under Ambiguity: A Study of US Venture Capital Firms' Investments in the Emerging Clean Energy Sector. Academy of Management Journal, 57, 1077-1093. https://doi.org/10.5465/amj.2011.0651

[17] Lee, P.M., Pollock, T.G. and Jin, K. (2011) The Contingent Value of Venture Capitalist Reputation. Strategic Organization, 9, 33-69. https://doi.org/10.1177/1476127011400505

[18] Megginson, WL and Kathleen, AM. (1991) Venture Capitalist Certification in Initial Public Offerings. Journal of Finance, 46, 879-903. https://doi.org/10.1111/j.1540-6261.1991.tb03770.x

[19] Zheng, X.J. (2010) Research on the Impact of the Reputation of Chinese Listed Companies on Corporate Performance. Economic Science Press, Beijing.

[20] Zheng, X.T. (2015) Research on the Influence Mechanism of the Reputation of Venture Capital Institutions on Investment Behavior. PhD Thesis, Zhejiang Gongshang University, Hangzhou. 